\title{
FAKTOR-FAKTOR YANG BERHUBUNGAN DENGAN KECELAKAAN TERTUSUK JARUM SUNTIK PADA PERAWAT
}

\author{
Herlinawati $^{1)}$, Rokhmatul Hikmat ${ }^{2)}$, Suzana Indragiri ${ }^{3)}$, Riani Andriyani Hidayat ${ }^{4}$ \\ 1,2,3,4 Sekolah Tinggi Ilmu Kesehatan Cirebon \\ Email : linacirebon57@gmail.com
}

\begin{abstract}
Abstrak
Berdasarkan data yang diperoleh dari Pengendalian dan Pencegahan Infeksi (PPI) terjadi kasus kecelakaan tertusuk jarum suntik pada tahun 2018-Mei 2019 sebanyak 6 kasus. Tertusuk jarum suntik merupakan kecelakaan yang tidak dikehendaki dan bila terpajan patogen darah dapat berdampak infeksi Tujuan dari penelitian ini adalah untuk mengetahui faktor-faktor yang berhubungan dengan kecelakaan tertusuk jarum suntik pada perawat. Penelitian ini menggunakan pendekatan kuantitatif dengan desain penelitian cross sectional. Populasi adalah perawat Unit Rawat Inap, Instalasi Gawat Darurat (IGD) dan Intensive Care Unit (ICU) sebanyak 150 orang. Jumlah sampel 60 orang yang diambil secara proportional random sampling. Data di ambil pada tanggal 15 -27 Juli 2019 menggunakan wawancara dengan instrumen kuesioner, kuesioner mengadopsi pertanyaan dari penelitian Ristiani (2017) dan Muslim et al (2013) yang sudah di lakukan uji validits reliabilitas. Analisis data menggunakan uji chi-square. Hasil uji statistik didapatkan bahwa pelatihan $(\mathrm{p}=0,011)$ dan standar kerja $(\mathrm{p}=0,002)$ mempunyai hubungan yang bermakna dengan kecelakaan tertusuk jarum suntik. Sedangkan kewaspadaan universal $(p=0,356)$ dan pengetahuan $(p=0,643)$ tidak mempunyai hubungan yang bermakna dengan kecelakaan tertusuk jarum suntik.
\end{abstract}

Kata Kunci: Pelatihan, Standar Kerja, Kewaspadaan Universal

\begin{abstract}
Based on data derived from Infection Control and Prevention (PPI), there were 6 cases of needle stick injury (NSI) in 2018-May 2019. NSI is a kind of unwanted accident and an exposure to blood pathogens may cause infection. This study aims to determine the factors correlated with the incidents of needle stick injury among nurses. This was a quantitative study with a cross sectional design. The population involved 150 nurses in the Inpatient Unit, Emergency Unit and Intensive Care Unit (ICU). The study samples were 60 nurses who were selected through proportional random sampling. The Data taken on July, 15-27, 2019 using questionnaire instrument. Quetionnaire deal with the research's question, Ristiani (2017) and Muslim et al (2013) which has been tested for validity and Reliability. Data were analyzed using chi-square test. The results of statistical tests showed that training ( $p=0.011)$ and work standards $(p=0.002)$ had a significant correlation with the incidents of needle stick injury. Meanwhile, universal precautions $(p=0.356)$ and knowledge $(p=0.643)$ did not show a significant correlation with the incidents of needle stick injury.
\end{abstract}

Keywords: Training, Work Standards, Universal Precautions

\section{PENDAHULUAN}

Rumah Sakit merupakan bagian integral dari sistem kesehatan di Indonesia yang menyelenggarakan pelayanan kesehatan secara komprehensif yang meliputi upaya-upaya kesehatan berupa upaya pencegahan penyakit (preventif), peningkatan kesehatan (promotif), penyembuhan (kuratif), dan pemulihan (rehabilitatif) yang bersifat menyeluruh, terpadu, dan berkesinambungan dipengaruhi oleh berbagai faktor lingkungan sosial, budaya, termasuk ekonomi, lingkungan fisik dan biologis yang bersifat dinamis dan kompleks. Selain itu, rumah sakit juga menghasilkan berbagai bahaya yang dapat menimpa para petugas kesehatan seperti terpajan agen biologis, bakteri, virus, dan bloodborne pathogen yang media penularannya melalui inhalasi, kontak kulit serta luka akibat tusukan jarum suntik yang terkontaminasi(Ristiani, 2017). 
Rumah sakit memiliki banyak potensi sumber bahaya bagi keselamatan dan kesehatan kerja (K3) terhadap para perawatnya. Salah satunya adalah infeksi nosokomial, yang disebabkan oleh cedera tertusuk dan atau tersayat (CTS). Pekerja kesehatan berisiko terpapar darah dan cairan tubuh yang terinfeksi (bloodborne pathogen) dan dapat menimbulkan risiko penularan virus lewat darah $\mathrm{HBV}, \mathrm{HCV}$, dan HIV(Ismara, 2020).

World Health Organization (WHO) menunjukkan setiap tahun bahwa sekitar 2,5\% petugas kesehatan di seluruh dunia menghadapi pajanan HIV, dan sekitar $40 \%$ menghadapi pajanan virus Hepatitis B dan Hepatitis $\mathrm{C}$ akibat pajanan darah yang terjadi di tempat kerja salah satunya melalui luka tusukan jarum bekas pakai yang telah terkontaminasi(Ristiani, 2017).

Hasil laporan National Safety Council (NSC) tahun 2008 menunjukkan bahwa terjadinya kecelakaan di rumah sakit $41 \%$ lebih besar dari pekerja industri lain. Kasus yang sering terjadi adalah tertusuk jarum, terkilir, sakit pinggang, tergores/terpotong, luka bakar, dan penyakit infeksi dan lain-lainWidowati, 2018).

Hasil riset National Safety Council (NSC) menunjukkan bahwa penyebab kecelakaan kerja $88 \%$ adalah adanya unsafe behavior, $10 \%$ karena unsafe condition dan $2 \%$ tidak diketahui penyebabnya. Di Indonesia dicatat bahwa proporsi luka tusuk jarum mencapai 38$73 \%$ pada perawat, dan selama tahun 2015 terdapat 70 insiden tertusuk jarum suntik. Pada setiap negara mempunyai data atau laporan tentang Needle Stick Injury (NSI), baik pada tingkat negara, provinsi maupun institusi. Secara umum kejadian Needle Stick Injury (NSI) ini banyak dialami oleh perawa(Ismara, 2020).

Tertusuk jarum suntik merupakan kecelakaan yang tidak dikehendaki dan bila terpajan patogen darah dapat berdampak infeksi. Faktor-faktor yang berkontribusi terhadap kecelakaan tertusuk jarum suntik diantaranya termasuk pengetahuan yaitu kemampuan sesorang perawat dalam mengevaluasi suatu kejadian yang tidak dikehendaki, standar kerja merupakan arahan kegiatan untuk mencapai tujuan yang efektif dan efisien sehingga konsisten dan aman dalam pemenuhan standar yang berlaku, pelatihan yaitu upaya untuk meningkatkan dan menambahkan pengetahuan, keterampilan dan pengalaman kerja, kewaspadaan universal merupakan tindakan pengendalian infeksi untuk mengurangi risiko penyebaran infeksi(Intan, 2013).

Penelitian Johan intan (2013) menunjukkan bahwa faktor yang mendasari terjadinya luka tusuk jarum suntik meliputi persepsi terhadap risiko luka tusuk jarum suntik, pengetahuan dan pemberlakuan kewaspadaan universal, prosedur/standar kerja, dan kepatuhan pelaksnaan kewaspadaan universal(Intan, 2013).

Hasil penelitian Septi Tri Wijayantai mengenai faktor-faktor yang mempengaruhi perilaku perawat dan bidan dalam kejadian tertusuk jarum suntik di RS S Jakarta tahun 2017, berdasarkan uji fisher exact didapatkan hasil dengan nilai $\mathrm{p}=0,001$ yang menunjukkan pelatihan memiliki hubungan dengan perilaku perawat dan bidan dalam kejadian tertusuk jarum suntik(Tri Wijayanti, 2017).

Rumah Sakit Pertamina Cirebon (RSPC) Jawa Barat merupakan rumah sakit tipe $\mathrm{C}$ yang mampu memberikan pelayanan kedokteran subspesialis terbatas. Di Rumah Sakit Pertamina Cirebon (RSPC) upaya pencegahan terhadap kejadian tertusuk jarum yang diakibatkan oleh jarum suntik telah dilaksanakan secara terintegrasi dengan usaha pelaksanaan Standard Procedure Operational (SPO) yang telah disosialisasikan, safety briefing untuk setiap karyawan baru, orientasi daerah yang berpotensi bahaya, dan pemberian promosi kesehatan. Salah satu upaya dari Rumah Sakit Pertamina Cirebon (RSPC) adalah zero accident atau nihil kecelakaan, 
namun angka kejadian tertusuk jarum suntik masih tetap terjadi di setiap tahun, walaupun upaya pencegahan telah dilakukan(RS Pertamina, 2019).

Berdasarkan studi pendahuluan yang telah dilakukan pada tanggal 15 Mei 2019, data yang diperolah dari Pengendalian dan Pencegahan Infeksi (PPI) terjadi kasus kecelakaan tertusuk jarum suntik pada tahun 2016 sebanyak 18 kasus, pada tahun 2017 sebanyak 12 kasus dan pada tahun 2018-Mei 2019 sebanyak 6 kasus. Terjadi kasus tertusuk jarum adalah pada saat pengambilan jarum suntik bekas pakai dan setelah cek Gula Darah Sewaktu (GDS) pasien. Awalnya perawat yang pernah tertusuk jarum suntik tidak ingin melaporkan kejadian tersebut ke bagian PPI, namun HSE Rumah Sakit Pertamina Cirebon memberi himbauan bahwa luka tusuk akibat jarum suntik bisa berisiko menularkan penyakit dari jarum suntik bekas pasien. Pelaporan kejadian tertusuk jarum di Rumah Sakit Pertamina Cirebon (RSPC) dilakukan oleh perawat yang ada di rumah sakit terebu (RS Pertamina, 2019).

\section{METODE PENELITIAN}

Penelitian ini menggunakan metode rancangan pendekatan kuantitatif dengan desain penelitian cross sectional.(Ahmad Watik P, 2011).

Populasi pada penelitian ini adalah perawat yang bertugas di Unit Rawat Inap sebanyak 66 orang, Instalasi Gawat Darurat (IGD) sebanyak 72 orang, Intensive Care Unit (ICU) sebanyak 12. Sehingga populasi penelitian sebanyak 150 orang pada periode bulan Mei 2019.

Teknik pengambilan sampel pada penelitian ini menggunakan teknik proportional random sampling atau pengambilan sampel acak berdasarkan area. Sampel yang diambil dari populasi penelitian ini sebanyak 150 orang pada perawat di RS Pertamina Cirebon, sampel berjumlah 60 perawat yang terdiri dari 27 perawat ruang rawat inap, 28 ruang Instalasi Gawat Darurat (IGD) dan 5 perawat di ruang Intensive Care Unit (ICU). Pengambilan sampel untuk masingmasing ruangan menggunakan teknik undian.

Data di kumpulkan dengan metode wawancara menggunakan kuesioner. Kuesioner berisi pertanyaan tentang kecelakaan tertusuk jarum suntik terdiri dari 1 pertanyaan dengan hasil ukur tidak pernah atau pernah terjadi kecelakaan dan skala ukur variabel nominal, variabel pelatihan terdiri dari 1 pertanyaan dengan hasil ukur tidak pernah atau pernah mendapatkan pelatihan dan skala ukur nominal, variabel kewaspadaan universal terdiri dari 8 pertanyaan, variabel standar kerja terdiri dari 5 pertanyaan dan variabel pengetahuan terdiri dari 12 pertanyaan di ukur dengan menggunakan skala Guttman (ya, tidak). Kemudian dikomposit dengan kategori kurang baik jika skor $\leq$ median dan baik jika skor $>$ median dan skala pengukuran ordinal.

Analisis univariat menggunakan distribusi frekuensi, sedangkan untuk mengetahui hubungan antara variabel dependen (kejadian tertusuk jarum suntik) dengan variabel independen (pengetahuan, standar kerja, pelatihan, kewaspadaan universal) uji statistik chi-square. Penelitian ini dilakukan di Rumah Sakit Pertamina Cirebon Jl. Patra Raya Klayan Cirebon.

\section{HASIL DAN PEMBAHASAN}

Tabel 1. Gambaran Pelatihan, Standar Kerja, Kewaspadaan Universal, Pengetahuan dan Kecelakaan Tertusuk Jarum Suntik

\begin{tabular}{lcc}
\hline Variabel & $\mathrm{n}$ & $\%$ \\
\hline Pelatihan & & \\
Tidak pernah & 33 & 41,7 \\
Pernah & 27 & 58,3 \\
\hline Standar Kerja & & \\
Kurang Baik & 35 & 58,3 \\
Baik & 25 & 41,7 \\
\hline Kewaspadaan & & \\
Universal & 21 & 35,0 \\
Kurang Baik & 39 & 65,0 \\
Baik & & \\
\hline
\end{tabular}




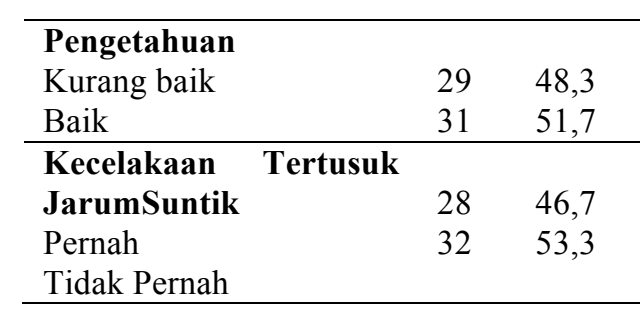

Tabel 1 menunjukkan bahwa lebih dari sebagian $33(55 \%)$ responden tidak pernah mendapatkan pelatihan, lebih dari sebagian $35(58,3 \%)$ responden kurang baik dalam standar kerja, sebagian besar $39(65 \%)$ responden menerapkan kewaspadaan universal dengan baik, lebih dari sebagian $31 \quad(51,7 \%)$ responden memiliki pengetahuan baik terkait tertusuk jarum suntik dan $46,7 \%$ responden pernah mengalami kecelakaan tertusuk jarum suntik.

Ditemukannya $55 \%$ pearwat yang belum pernah mendapatkan pelatihan memiliki risiko lebih banyak mengalami kecelakaan kerja dibandingkan dengan responden yang pernah mendapatkan pelatihan.

Dalam upaya untuk meningkatkan dan menambah pengetahuan, keterampilan dan pengalaman pegawai rumah sakit dalam melaksanakan kegiatan/unsur-unsur dengan K3 maka perlu untuk melakukan pelatihan. Tujuan diselenggarakannya diklat adalah untuk membentuk karyawan yang peka, tanggap dan waspada terhadap keselamatan dan kesehatan kerja (K3) sehingga mempunyai kesadaran dan kemampuan untuk melakukan kegiatankegiatan saat bekerja(Widowati, 2018).

Sejumlah $58 \%$ persen perawat yang tidak menerapkan standar kerja karena melakukan tindakan berdasarkan rutinitas dan pengalaman yang didapat semasa pendidikan terdahulu standar kerja yang telah dimiliki hanya digunakan sebagai pelengkap dokumen. Meskipun demikian pelaksanaan standar kerja yang ada di Rumah Sakit Pertamina Cirebon sudah baik.

Berbeda dengan penelitian Ketut Ima Ismara bahwa $52 \%$ perawat sudah melaksanakan perilaku tugas pokok sesuai dengan prosedur $\mathrm{K} 3$ terkait dengan pencegahan CTS("Hospital Safety.," 1966). Standar Prosedur Operasional di buat untuk mengarahkan kegiatan untuk mencapai tujuan yang efisien dan efektif sehingga konsisten dan aman dalam meningkatkan mutu pelayanan melalui pemenuhan standar yang berlaku(Departemen Kesehatan, 2005).

Sejumlah $65 \%$ perawat sudah memiliki kewaspadaan universal yang baik. Perawat menerapkan kewaspaaan universal didasarkan pada keyakinan bahwa darah atau cairan tubuh sangat berpotensial menularkan penyakit, baik yang berasal dari pasien maupun petugas kesehatan. Prinsip utama kewaspadaan universal ialah menjaga higiene sanitasi individu, higiene sanitasi ruangan dan sterilisasi peralatan.

Penerapan kewaspadaan universal di suatu pelayanan kesehatan akan tergantung pada tersedianya peralatan medik dan sarana yang dibutuhkan. Ketersediaan dan kemudahan mendapatkan alat merupakan faktor yang memegang peranan penting dalam mematuhi kewaspadaan universal. Kewaspadaan universal menekankan kepada penerapan individual tentang tindakan preventif, termasuk menggunakan pelindung, cuci tangan dan pengolahan peralatan seperti peralatan tajam untuk mempersempit kejadian terpapar darah pasien dan cairan tubuh lainnya. Penerapan kewaspadaan universal berhubungan dengan kewaspadaan diri terhadap risiko terpapar atau terpajan infeksi.

Sebanyak $51,7 \%$ perawat sudah memiliki pengetahuan yang baik terkait bahaya, risiko, pencegahan, pengendalian dan penanganan kecelakaan akibat tertusuk jarum suntik.

Menurut Notoatmodjo menyatakan bahwa pengetahuan adalah hasil tahu dan ini terjadi setelah orang melakukan penginderaan terhadap suatu objek tertentu. Penginderaan terjadi melalui panca indera manusia, yakni indera penglihatan, pendengaran, penciuman, rasa dan raba. Sebagian besar pengetahuan 
manusia diperoleh melalui mata dan telinga. Pengetahuan merupakan domain yang sangat penting untuk terbentuknya tindakan seseorang (over behaviour), karena dari pengalaman dan penelitiannya ternyata perilaku yang didasarkan oleh pengetahuan akan lebih langgeng daripada perilaku yang tidak di sadari oleh pengetahuan(Notoatmodjo, 2012).
Sebanyak $46,7 \%$ responden pernah mengalami kecelakaan tertusuk jarum suntik. Kejadian cedera tertusuk jarum suntik disebabkan oleh, perilaku perawat yang tidak aman, penempatan peralatan medis secara sembarangan, tidak taat prosedur, tidak memakai alat pelindung diri (APD) dan wadah limbah jarum suntik atau benda tajam, tidak tersedia atau kurang terjangkau(CDC, 2008).

Tabel 2. Hubungan Pelatihan Dengan Kecelakaan Tertusuk Jarum Suntik

\begin{tabular}{|c|c|c|c|c|c|c|c|}
\hline \multirow{3}{*}{ Pelatihan } & \multicolumn{4}{|c|}{ Kecelakaan Tertusuk Jarum Suntik } & \multirow{2}{*}{\multicolumn{2}{|c|}{ Jumlah }} & \multirow{3}{*}{ P Value } \\
\hline & \multicolumn{2}{|c|}{ Tidak Pernah } & \multicolumn{2}{|c|}{ Pernah } & & & \\
\hline & $\mathrm{n}$ & $\%$ & $\mathrm{n}$ & $\%$ & $\mathrm{~N}$ & $\%$ & \\
\hline Tidak Pernah & 10 & 30,3 & 23 & 69,7 & 33 & 100 & \\
\hline Pernah & 18 & 66,7 & 9 & 33,3 & 27 & 100 & 0,011 \\
\hline Jumlah & 28 & 46,7 & 32 & 53,3 & 60 & 100 & \\
\hline
\end{tabular}

Berdasarkan tabel 2 menunjukkan bahwa responden yang tidak pernah mendapatkan pelatihan sebagian besar $(69,7 \%)$ pernah mengalami kecelakaan tertusuk jarum suntik, sedangkan responden yang pernah mendapatkan pelatihan sebgaian besar $(66,7 \%)$ tidak pernah mengalami kecelakaan tertusuk jarum suntik. Hasil uji statsitik menunjukkan bahwa nilai $\mathrm{P}$ value $=0,011$ $(\alpha=0,05)$ berarti ada hubungan antara pelatihan dengan kecelakaan tertusuk jarum suntik.

Hasil penelitian ini sejalan dengan penelitian Sylvia Puspitasari (2018) menunjukkan bahwa terdapat hubungan yang signifikan antara pelatihan dengan kecelakaan kerja tertusuk jarum suntik atau benda tajam lainnya. Faktor yang paling besar pengaruhnya adalah factor pelatihan, sehingga memiliki resiko 3,566 kali lebih besar mengalami kejadian kecelakaan(Puspitasari \& Ginanjar, 2019).

Penelitian Awaliyah Ulfah (2018) menunjukkan bahwa adanya pengaruh yang signifikan antara mean nilai pemahaman perawat tentang penerapan keselamatan pasien sebelum dan setelah dilakukan pelatihan dengan metode ceramah(Ayudhita et al., 2018).
Pelatihan adalah bagian penting dalam program pengendalian bahaya yang merupakan bagian dari program Keselamatan dan Kesehatan Kerja (K3) yang dilakukan secara komprehensif di tempat kerja. Pelatihan secaraa signifikan dapat mengurangi biaya yang di keluarkan dalam menangani kecelakaan. Jika perawat yang tidak mengikuti pelatihan mempunyai risiko luka tusuk jarum yang lebih tinggi dibandingkan perawat yang mengikuti pelatihan(Widowati, 2018).

Sebaiknya pihak Rumah Sakit memberi perhatian besar terhadap perawat terkait bahaya risiko dari kecelakaan tertusuk jarum suntik, upaya pencegahan kecelakaan akibat tertusuk jarum suntik bisa dilakukan dengan mengadakan pelatihan berkala untuk menambah keterampilan dan pengetahuan perawat terhadap kecelakaan tertusuk jarum suntik. Setelah pemberian pelatihan yang bertujuan agar materi yang telah didapat oleh perawat bisa menjadi bagian dari sikap yang menjadi dasar perawat melakukan tindakan dalam menggunakan jarum suntik. 
Tabel 3. Hubungan Standar Kerja Dengan Kecelakaan Tertusuk Jarum Suntik

\begin{tabular}{|c|c|c|c|c|c|c|c|}
\hline \multirow{3}{*}{ Standar Kerja } & \multicolumn{4}{|c|}{ Kecelakaan Tertusuk Jarum Suntik } & \multirow{2}{*}{\multicolumn{2}{|c|}{ Jumlah }} & \multirow{3}{*}{ P Value } \\
\hline & \multicolumn{2}{|c|}{ Tidak Pernah } & \multicolumn{2}{|c|}{ Pernah } & & & \\
\hline & $\mathrm{N}$ & $\%$ & $\mathrm{n}$ & $\%$ & $\mathrm{~N}$ & $\%$ & \\
\hline Kurang Baik & 10 & 28,6 & 25 & 71,4 & 35 & 100 & \\
\hline Baik & 18 & 72 & 7 & 28 & 25 & 100 & 0,002 \\
\hline Jumlah & 28 & 46,7 & 32 & 53,3 & 60 & 100 & \\
\hline
\end{tabular}

Berdasarkan tabel 3 menunjukkan bahwa responden yang memiliki standar kerja kurang baik sebagian besar $(71,4 \%)$ pernah mengalami kecelakaan tertusuk jarum suntik, sedangkan responden yang memiliki standar kerja yang kurang baik sebagian besar $(72 \%)$ pernah mengalami kecelakaan tertusuk jarum suntik Hasil uji statistic menunjukkan bahwa nilai Pvalue $=$ $0,002(\alpha=0,05)$ berarti ada hubungan antara standar kerja dengan kecelakaan tertusuk jarum suntik.

Hasil penelitian ini sejalan dengan penelitian Silvia Maria tentang kejadian kecelakaan kerja perawat berdasarkan tindakan tidak aman di RS Panti Waluya Malang, yang menyatakan bahwa adanya hubungan antara kecelakaan kerja dengan tindakan tidak aman(Maria, 2015). Penelitian Abdul Muslim (2013) di dapatkan hasil bahwa penerapan SOP berpengaruh dengan kejadian tertusk jarum suntik pada perawat di RD Kendal.(Muslim et al., 2013).
Standar kerja adalah suatu perangkat instruksi atau langkah kegiatan yang dibakukan untuk memenuhi kebutuhan tertentu klien, merupakan tata cara atau tahapan yang harus dilalui dalam suatu proses kerja yang dapat dipertanggungjawabkan sehingga suatu kegiatan dapat diselesaikan secara efektif dan efisien(Departemen Kesehatan, 2005).

Karena kurangnya pengawasan dari pihak rumah sakit dalam melakukan tindakan kegiatan menyuntik atau pengambilan darah, perawat seharusnya menjalankan kegiatan kerja dengan memperhatikan standar yang telah dibuat. Meskipun telah memiliki standar kerja terkadang para perawat tidak menerapkan standar kerja tersebut dalam melakukan tindakan karena para perawat sudah terbiasa dengan rutinitas dan pengalaman yang didapat sebelumnya.

\section{Tabel 4. Hubungan Kewaspadaan Universal Dengan Kecelakaan Tertusuk Jarum}

\section{Suntik}

\begin{tabular}{lllllll}
\hline \multirow{2}{*}{$\begin{array}{l}\text { Kewaspadaan } \\
\text { Universal }\end{array}$} & \multicolumn{9}{l}{ Kecelakaan Tertusuk Jarum Suntik } & \multirow{2}{*}{ Jumlah } & \multirow{2}{*}{ P Value } \\
\cline { 2 - 7 } & $\mathrm{T}$ Tidak Pernah & Pernah & & \\
\cline { 2 - 7 } & $\mathrm{N}$ & $\%$ & $\mathrm{~N}$ & $\%$ & $\mathrm{~N}$ & $\%$ \\
\hline Kurang Baik & 12 & 57,1 & 9 & 42,9 & 21 & 100 \\
Baik & 16 & 41 & 23 & 59 & 39 & 100 \\
\hline Jumlah & 28 & 46,7 & 32 & 53,3 & 60 & 100 \\
\hline
\end{tabular}

Berdasarkan tabel 4 menunjukkan bahwa responden yang memiliki kewaspadaan universal kurang baik lebih dari sebagian $(57,1 \%)$ tidak pernah mengalami kecelakaan tertusuk jarum suntik begitupun responden yang memiliki kewaspadaan universal yang baik lebih dari sebagian $(59 \%)$ pernah mengalami kecelakaan tertusuk jarum suntik. Hasil uji statistik menunjukkan nilai Pvalue $=0,356$ $(\alpha=0,05)$ berarti tidak ada hubungan 
antara kewaspadaan universal dengan kecelakaan tertusuk jarum suntik.

Penelitian ini tidak sejalan dengan Nurkhasanah (2014) yang menyatakan bahwa kewaspadaan universal merupakan startegi yang direkomendasikan center for desesase control and prevention sebagai upaya pencegahan infeksi dan penularan penyakit pada tenaga kesehatan(Nurkhasanah \& Sujianto, 2014).

Kewaspadaan universal yaitu tindakan pengendalian infeksi yang dilakukan oleh seluruh tenaga kesehatan untuk mengurangi resiko penyebaran infeksi dan didasarkan pada prinsip bahwa darah dan cairan tubuh dapat berpotensi menularkan penyakit(Nursalam, 2007).

Penerapan kewaspadaan universal diharapkan dapat menurunkan risiko penularan patogen melalui darah dan cairan tubuh lain dari sumber yang diketahui maupun yang tidak diketahui. Penerapan ini merupakan pencegahan dan pengendalian infeksi yang harus rutin dilaksanakan dan disemua fasilitas pelayanan kesehatan(Gultom et al., 2016).

Dalam penelitian ini kewaspadaan tidak memiliki hubungan dengan kecelakaan tertusuk jarum, walaupun perawat sudah menerapkan kewaspadaan universal tetapi faktor lain seperti kelelahan, beban kerja dan kurangnya konsentarsi karena banyaknya pasien memungkinkan untuk terjadinya kecelakaan. Faktor keterbatasan sumberdaya manusia pemberi pelayanan berpengaruh terhadap standar pelayanan minimal(Suartini et al., 2020).Bekerja di lingkungan kerja yang buruk dalam hal staf dan kecukupan sumber daya, dan mengalami kelelahan emosional yang tinggi memiliki risiko Needlestick and sharp injuries (NSIs) yang jauh lebih tinggi.(Cho E. , Lee H., 2014).

Tabel 5 Hubungan Pengetahuan Dengan Kecelakaan Tertusuk Jarum Suntik

\begin{tabular}{|c|c|c|c|c|c|c|c|}
\hline \multirow{3}{*}{ Pengetahuan } & \multicolumn{4}{|c|}{ Kecelakaan Tertusuk Jarum Suntik } & \multirow{2}{*}{\multicolumn{2}{|c|}{ Jumlah }} & \multirow{3}{*}{ P Value } \\
\hline & \multicolumn{2}{|c|}{ Tidak Pernah } & \multicolumn{2}{|c|}{ Pernah } & & & \\
\hline & $\mathrm{n}$ & $\%$ & $\mathrm{n}$ & $\%$ & $\mathrm{~N}$ & $\%$ & \\
\hline Kurang Baik & 7 & 28 & 18 & 72 & 25 & 100 & \\
\hline Baik & 13 & 37,1 & 22 & 62,9 & 35 & 100 & 0,643 \\
\hline Jumlah & 20 & 33,3 & 40 & 66,7 & 60 & 100 & \\
\hline
\end{tabular}

Berdasarkan tabel 5 menunjukkan responden yang memiliki pengetahuan yang kurang baik sebgaian besar $(72 \%)$ pernah mengalami kecelakaan tertusuk jarum suntik, begitupun responden yang memiliki pengetahuan yang baik sebagian besar $(62,9 \%)$ pernah mengalami kecelakaan tertusuk jarum suntik. Hasil uji statistik menunjukkan nilai Pvalue $=0,643$ $(\alpha=0,05)$ berarti tidak ada hubungan antara pengetahuan dengan kecelakaan tertusuk jarum suntik.

Hasil tersebut tidak sesuai dengan penelitian Sarah Mapanawang (2017) yang menunjukkan bahwa terdapat hubungan yang bermakna antara pengetahuan dengan kejadian luka tusuk jarum suntik pada perawat di RSUD Liun Kendage(Mapanawang, Sarah:Pandelaki, Karel;Panelewen, 2018).

Pengetahuan merupakan faktor yang mempengaruhi cara berpikir atau bertindak seseorang ketika melakukan pekerjan. Kurangnya pengetahuan khususnya tentang kesehatan kecelakaan kerja menyebabkan perawat kurang menyadari pentingnya keselamatan dalam bekerja sehingga dapat mengakibatkan kejadian kecelakaan kerja. 
Dalam penelitian ini pengetahuan tidak berhubungan, hal ini di karenakan responden yang berpengetahuan baik, tidak mengaplikasikan apa yang diketahuinya sehingga realisasi terhadap perilaku pencegahan berkurang. Hal ini ditunjukkan $72 \%$ yang memiliki pengetahuan baik pernah mengalami luka tertusuk jarum suntik.

Sejalan dengan hasil penelitian Herlinawati (2018) menunjukkan bahwa tidak ada hubungan pengetahuan dengan perilaku pertolongan pertama pada kecelakaan (P3K). Karyawan yang memiliki pengetahuan tinggi tentang P3K mereka mengerti tindakan $\mathrm{P} 3 \mathrm{~K}$, namun belum tentu dalam parkteknya mereka bisa melakukan tindakan P3K dengan baik dan benar. Pada kenyataannya karyawan yang memiliki pengetahuan tinggi dengan karyawan yang memiliki pengetahuan rendah tentang $\mathrm{P} 3 \mathrm{~K}$ keduanya memiliki proporsi yang tidak berbeda jauh untuk tidak melakukan tindakan P3K di tempat kerja(Herlinawati \& Azhari, 2020).

\section{SIMPULAN}

Variabel pelatihan dan standar kerja memiliki hubungan dengan kejadian tertusuk jarum, sedangkan variabel yang tidak berhubungan adalah kewaspadaan universal dan pengetahuan. Pelatihan harus diberikan secara berkala, sehingga dapat terus meningkatkan kompetensi dan mengurangi resiko kecelakaan, perawat yang memiliki pengetahuan tinggi masih banyak yang mengalami kecelakaan tertusuk jarum karena melakukan tndakan mengikuti rutinitas untuk sosialisasi standar operational prosedur (SOP) dilakukan secara continue agar dapat meningkatkan kesadaran masing-masing individu untuk melatih budaya kerja secara aman.

\section{UCAPAN TERIMAKASIH}

Penelitian ini dapat terlaksana dengan bantuan berbagai pihak. Oleh karena itu peneliti dengan sepenuh hati menyampaikan rasa terima kasih kepada seluruh civitas akademika STIKe Cirebon.

\section{DAFTAR PUSTAKA}

Ahmad Watik P. (2011). Dasar-dasar Metodologi Penelitian Kedokteran dan Kesehatan. Rajagrafindo Husada. Ayudhita, A. U., Anggreini, S. N., \& Putri, D. E. (2018). Pengaruh Pelatihan Keselamatan Pasien Dengan Metode Ceramah Terhadap Pemahaman Perawat Mengenai Penerapan Sasaran Keselamatan Pasien Di Rs Pmc Pekanbaru. Health Care: Jurnal Kesehatan, 7(2), 1-8. https://doi.org/10.36763/healthcare.v7 i2.23

CDC. (2008). Work book for designing, implementing and evaluating a sharps injury prevention program. https://www.cdc.gov/sharpssafety/pdf /sharpsworkbook_2008.pdf

Cho E. , Lee H., C. M. et al. (2014). Factors associated with needlestick and sharp injuries among hospital nurses. Int $J$ Nurs Stud. R.Korea, $50(8)$, 1025-1032. https://doi.org/10.1016/j.ijnurstu.2012 .07.009.Factors

Departemen Kesehatan. (2005). Instrumen Evaluasi Penetapan Standar Asuhan Keperawatan di Rumah Sakit. Departemen Kesehatan.

Gultom, A., Umboh, J. M. ., \& Polii, B. (2016). Faktor-Faktor Yang Berhubungan Dengan Penerapan Kewaspadaan Universal (Universal Precaution) Oleh Perawat Di Ruang Rawat Inap Penyakit Dalam (Irina C) RSUP. PROF. Dr. R. D. Kandau Manado. Public Health Journal, 4(3), 36.

Herlinawati, H., \& Azhari, T. (2020). Hubungan Pengetahuan Dan Sikap Dengan Perilaku Pertolongan Pertama Pada Kecelakaan (P3K) Pada Karyawan Gedung E Bagian Benang. Jurnal Kesehatan, 9(1), 1040-1047. https://doi.org/10.38165/jk.v9i1.72 
Hospital safety. (1966). Manitoba Medical Review, 46(2), 143-145.

Intan, J. (2013). Faktor-faktor yang berhubungan dengan terjadinya luka tusuk jarum pada paramedis di RUMKITAL dr. Midiyato $S$ Tanjungpinang.

Ismara, K. I. M. A. (2020). Perilaku Mencegah Cedera Tertusuk daN Tersayat (CTS).

Mapanawang, Sarah:Pandelaki, Karel;Panelewen, J. (2018). Hubungan Antara Pengetahuan, Kompetensi, Lama Kerja, Beban Kerja Dengan Kejadian Tertusuk Jarum Suntik Pada Perawat Di Rsud Liun Kendage Tahuna. Jurnal EMBA: Jurnal Riset Ekonomi, Manajemen, Bisnis Dan Akuntansi, 5(3), 43364345.

https://doi.org/10.35794/emba.v5i3.1 9091

Maria, S. (2015). Kejadian Kecelakaan Kerja Perawat Berdasarkan Tindakan Tidak Aman. Jurnal Care, 3(2), 1011.

Muslim, A., Widjaksena, B., \& Musyarofah, S. (2013). Faktor-Faktor Yang Mempengaruhi Kejadian Tertusuk Jarum Suntik Pada Perawat. Jurnal Ilmah STIKES Kendal, 3(2), 36-44.

Notoatmodjo, S. (2012). Promosi Kesehatan dan Perilaku Kesehatan. Rineka Cipta.

Nurkhasanah, \& Sujianto, U. (2014). Prosiding konferensi nasional ii ppni jawa tengah 2014 kepatuhan perawat dalam penerapan kewaspadaan universal di rumah sakit dokter kariadi semarang tahun 2013. Prosiding Konferensi Nasional Ii Ppni Jawa Tengah, 222-228. https://jurnal.unimus.ac.id/index.php/ psn12012010/article/download/1146/ 1200

Nursalam. (2007). Manajemen Keperawatan dan Aplikasinya. Salemba Medika.

Puspitasari, S., \& Ginanjar, R. (2019).
Faktor-Faktor Yang Berhubungan Dengan Kecelakaan Pada Perawat Di Rsud Leuwiliang Kabupaten Bogor Tahun 2018. Jurnal Mahasiswa Kesehatan Masyarakat, 2(2), 163171.

Ristiani, S. A. (2017). Faktor-faktor yang Berhubungan dengan Terjadinya Luka Tusuk Jarum atau Benda Tajam Lainnya Pada Perawat di Rumah Sakit Umum Daerah (RSUD) Dr. Pringadi Kota Medan. Universitas Sumatera Utara.

RS Pertamina. (2019). Data-data HSE Company Profile Rumah Sakit Pertamina Cirebon.

Suartini, D. N., Syamsul, A., Jamal, B., Budi, A., \& Keperawatan, J. (2020). IMPLEMENTASI STANDAR PELAYANAN MINIMAL.

Tri Wijayanti, S. (2017). Faktor-faktor yang Berhubungan dengan Terjadinya Luka Tusuk Jarum Suntik pada Perawat dan Bidan di Rumah Sakit $S$ Jakarta. Universitas Esa Unggul.

Widowati, A. (2018). Kesehatan dan Keselamatan Kerja Rumah Sakit Untuk Mahasiswa dan Rumah Sakit. Trans Info Media. 